\title{
The impact of the perceived risk of COVID-19 on consumers' attitude and behavior toward locally produced food
}

\author{
Ramon Palau-Saumell, Jorge Matute, Belén Derqui and \\ Jan-Hinrich Meyer \\ Business Management, IQS School of Management, Universitat Ramon Llull, \\ Barcelona, Spain
}

Perceived risk of COVID-19 on consumers

Received 9 April 2021 Revised 22 June 2021 Accepted 1 July 2021

\begin{abstract}
Purpose - This study analyzes the impact of the COVID-19 pandemic on the consumption of locally produced food. In particular, it examines an extended model of the theory of planned behavior, with the addition of the perceived risk of becoming infected with the disease, locavorism and internal locus of control.

Design/methodology/approach - The study employs data collected from an online panel of consumers from the five largest cities in Spain $(n=1,000)$. It uses partial least squares structural equation modeling (PLSSEM) to test and validate the proposed theoretical model.

Findings - The results indicate that the perceived risk of COVID-19 drives consumers to embrace locavorism more and, although locavorism is a strong predictor of attitude, internal locus of control also has a strong impact on attitude and switching intentions. Subjective norm and attitude are strong predictors of switching intentions and purchase intentions, and switching intentions also have a powerful impact on purchase intentions.

Originality/value - This study extends previous research on locally produced food consumption in that it has proposed and tested a new conceptual model with the inclusion of the perceived risk of COVID-19, locavorism, internal locus of control and switching intentions, which were found to have an influence on purchasing behavior.
\end{abstract}

Keywords COVID-19, Pandemic, Locavorism, Internal locus of control, Switching intentions, Subjective norm, Attitude, Purchase intentions, PLS-SEM, TPB, Local food, Zero-mile

Paper type Research paper

\section{Introduction}

The already growing preference for local products and brands before the COVID-19 pandemic has been accelerated by the effects of lockdown and the restrictions on mobility throughout the health crisis (Nielsen, 2020). Local products, in addition to being more robust to breaks in the supply chain, have allowed consumers to have a guaranteed supply, to gain confidence in these products and to believe that supporting them will improve local economies (Nielsen, 2020). Early studies, although still highly exploratory, suggested that the COVID-19 crisis has pushed consumers to change their food purchasing habits. For example, in France, awareness of the importance of sustainable food choices has increased, which has

(C) Ramon Palau-Saumell, Jorge Matute, Belén Derqui and Jan-Hinrich Meyer. Published by Emerald Publishing Limited. This article is published under the Creative Commons Attribution (CC BY 4.0) licence. Anyone may reproduce, distribute, translate and create derivative works of this article (for both commercial and non-commercial purposes), subject to full attribution to the original publication and authors. The full terms of this licence may be seen at http://creativecommons.org/licences/by/4.0/ legalcode

Funding: This work was supported by the Secretary of Universities and Research (Ministry of Business and Knowledge, Catalonia), and the Universitat Ramon Llull.

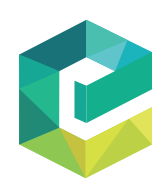

British Food Journa Vol. 123 No. 13, 2021 pp. 281-301 Emerald Publishing Limited DOI 10.1108/BFJ-04-2021-0380 
BFJ

123,13

in turn led to a greater consumption of ethical, healthy and natural food products (Marty et al., 2020). In China, the general attitudes of consumers toward organic foods became more positive, while they now have a more negative attitude toward game meat (Xie et al., 2020). In the UK, there was an increase in food purchases closer to home due to restrictions on mobility, which is why the use of local food retailing is on the rise (Cummins et al., 2020). In Spain, a study carried out between May and June 2020 highlighted that COVID-19 has increased consumers' preference for fresh, local products and for proximity stores. Around $20 \%$ of Spaniards had an enhanced interest in local products as well as in increasing their consumption of fresh fruit and vegetables, while between 10 and $15 \%$ reduced their consumption of pizzas and precooked foods (Rahmani et al., 2020). In addition to these changes in consumer trends, the situation of the pandemic began to be especially alarming during the second wave. The evolution of COVID-19 in Spain showed that from the 571 daily cases on July 1,2020, at the end of the first wave, the number increased to 10,682 on October 1, 2020 (Ministry of Health of Spain, 2020a). The total accumulated impact of the pandemic on that day was 769,188 cases and 31,791 deaths (Ministry of Health of Spain, 2020b).

The restrictions imposed by the government in combination with consumers' attempts to protect their own health and that of others caused dramatic changes in the food industry in Spain. On the one hand, online sales of food and grocery products via the platforms of hypermarkets, supermarkets and food stores underwent a 160\% increase between the first quarter of 2019 and the second quarter of 2020 (Statista, 2021). On the other hand, small local food businesses experienced major difficulties, as their main customers (i.e. restaurants) had to close due to the restrictions. To avoid bankruptcy, some of them joined the new online market place initiatives in order to reach consumers directly (La Vanguardia, 2020), since Spaniards backed local stores due to the proximity to their homes and the products on offer (Kantar, 2020).

In addition to this new situation caused by the pandemic, previous research revealed that some consumers prefer locally produced foods (LPF) because they are healthier, and they benefit the local communities on a social, economic and environmental level (Meyerding et al., 2019). Other researchers have argued that this trend has been driven by an emerging sociopolitical characteristic among consumers, known as locavorism (Zhang et al., 2020), which consists in the active defense of locally produced foods (Reich et al., 2018). Furthermore, it is known that in contexts in which consumers are committed to locally produced food, prices are not usually an impediment to stop them from buying it. This economic motivation is common for individuals with a higher internal locus of control (INLOC), as they tend to believe that their attitudes toward a product are related to their own behaviors (Cleveland et al., 2005).

However, it remains unknown whether the changes in the trend toward the consumption of locally produced foods reflected in the most recent data are driven by the effect of COVID-19. It is therefore important to investigate whether the perceived risk of becoming infected with the disease stimulates the expansion of locavorism among consumers. Previous research has also identified the effect of the INLOC on attitudinal and behavioral variables among consumers (Hwong et al., 2020; He et al., 2019). Yet, very little research has been conducted on the effect of the INLOC on attitudinal and behavioral variables in the context of locally produced food.

The theory of planned behavior (TPB) (Ajzen, 1991) is one of the most widely investigated models to predict behavioral intentions in order to understand consumption contexts (Hassan et al., 2016). In recent years, scholars have also developed and validated extended TPB models in order to improve their explanatory power in the food consumption markets (Boobalan and Nachimuthu, 2020; Brune et al., 2020). However, to date, no studies have evaluated the impact of COVID-19 risk perception, locavorism and INLOC on attitudes and behaviors regarding locally produced food. The current study has attempted to investigate the process of the 
formation of consumers' behavior toward locally produced food during the COVID-19 pandemic, through an extended model of the TPB that incorporated the previously mentioned variables. The inclusion of the perceived risk of being infected by COVID-19, locavorism and INLOC enriches the connotation of the TPB, thereby allowing the process of the formation of consumer behavior to be examined more thoroughly.

\section{Conceptual framework and research hypotheses}

\subsection{The theory of planned behavior}

The TPB postulates that the individual's behavior is predicted from the intention (referring to a person's intention to engage in a particular behavior). This, in turn, is determined by the attitude (ATT) (beliefs that exert a direct influence on the general intentions to change, and are crucial to foster individuals' positive or negative intentions), the subjective norm (SN) (the individual's perceptions regarding the opinions and behavior of people in their social groups, such as family, friends and peers, and in the community), and the perceived behavioral control $(\mathrm{PBC})$, that is, beliefs about the ability to control that facilitate or inhibit the performance of a behavior (Ajzen, 1991). In the context of this research, and regarding locally produced food products (LPF), two behavioral intentions are differentiated: switching intentions (SWI) and purchase intentions (PUR), both toward LPF. SWI refers to the possibility of a customer transferring the purchasing activities to another competitor. It is thus the opposite of loyalty and repurchase intentions, and it implies unfavorable outcomes for the brand or product that is currently purchased (Han et al., 2011). While loyalty entails positive consequences for a company, since its customer intends to purchase again, SWI denote the probability of changing from the current supplier to another (Wu and Cheng, 2016).

Previous research has identified a strong positive relationship between SWI and food shoppers' replacing the store they currently use (Hino, 2017). Therefore, SWI toward LPF are very likely to positively affect PUR toward LPF. Accordingly, the following hypothesis is proposed:

\section{H1. SWI toward LPF have a direct and positive effect on PUR toward LPF.}

An abundant body of previous literature has tested the causal relationships of the TPB in the context of LPF. For example, the SN has been identified as a predictor of purchase intentions in the context of fresh and organic food consumption (Dean et al., 2012; Basha and Lal, 2018). In accordance with the arguments set out above, favorable opinions of social groups toward the LPF are very likely to influence an individual's purchase intentions. So, the following hypothesis is proposed:

H2. SN has a direct and positive effect on PUR toward LPF.

Despite the fact that individuals seek relationships and have a propensity to display behavior that is appreciated by their reference groups, a limited number of studies conducted in the context of food research have included a positive effect of SN on SWI, although it has also been identified in other contexts (Sun et al., 2017). Hence, if this relationship has been tested in other contexts, it is also very likely to be found in the context of LPF. The following hypothesis is therefore proposed:

\section{H3. SN has a direct and positive effect on SWI toward LPF.}

The relationship between ATT and intention has been tested in many studies on food, and the positive influence of ATT on intentions has been widely supported, especially in the case of local food (Bavorava et al., 2018; Vabø and Hansen, 2016; Bianchi and Mortimer, 2015). As a consequence, the more positive individuals' attitudes toward consuming LPF are, the more likely they are to purchase LPF. Hence, the following hypothesis is proposed: 
BFJ

123,13

284

H4. ATT has a direct and positive effect on PUR toward LPF.

Previous literature has proven that behavioral attitudes, such as dissatisfaction with a product or service, increase SWI (Cho and Song, 2012). Therefore, a positive attitude toward LPF will positively impact the SWI from conventional food products to LPF.

H5. A positive ATT toward LPF has a direct and positive effect on SWI toward LPF. In this study, $\mathrm{PBC}$ refers to people's perception about product availability, and the additional effort needed to purchase LPF. Previous research has identified a positive relationship between $\mathrm{PBC}$ and purchase intentions, as well as in the context of local food consumption (Fiandari et al., 2019; Tomic et al., 2015). In addition, PBC influences SWI when consumers have the resources and opportunities to switch supplier (Farah, 2017). Based on the above, the following hypotheses are proposed:

H6. PBC has a direct and positive effect on PUR toward LPF.

H7. PBC has a direct and positive effect on SWI toward LPF.

\subsection{Locus of control}

The concept of locus of control (LOC) is related to the individual's perceptions of actual control over future events concerning themselves and the world around them (Bradley and Sparks, 2002). On some occasions, it has been confused with the PBC of TPB, but the PBC of an outcome or event is independent of the locus of the factors responsible for it (Ajzen, 2002).

The LOC can be internal or external (He et al., 2019). Specifically, individuals with an internal LOC (INLOC) differ from those who show an external LOC because the latter consider that their purchases will not bring about significant changes in their environment, as they consider such changes beyond their control, and instead attribute the responsibility to companies and governments. In contrast, the former believe that the individual has control over his or her future. People with an INLOC believe that their behavior will bring about changes in their environment because they have the ability to control any event as a result of this action (Patel et al., 2020). This holds, even when considering that the high price of LPF is usually the main barrier for consumers (Bryla, 2016; Khan and Prior, 2010), and even more so for consumers who usually purchase conventional food products (Padel and Foster, 2005).

Cleveland et al. (2005) developed a scale that included two dimensions of INLOC: individual recycling efforts and economic motivation. For the purposes of this study, and based on the arguments indicated above, economic motivation was selected as a unidimensional scale of the INLOC to measure its influence on attitude and SWI.

Previous research has shown that INLOC is a predictive factor of emotional (Hwang et al., 2020), attitudinal and behavioral variables (Trivedi et al., 2015). Specifically, in food consumption, INLOC has been found as an antecedent of attitude toward green products (Patel et al., 2020). However, the effect of the economic motivations of those with INLOC on ATT and SWI has hardly been studied. Given these findings, and in view of the fact that individuals with INLOC are more likely to adopt pro-environmental behaviors (Cleveland et al., 2020), the current study predicts that INLOC is likely to have a positive influence on SWI. Consequently, this prediction is reflected in the following hypothesis:

H8. INLOC has a direct and positive effect on SWI toward LPF.

In addition, previous literature has found that individuals with INLOC have a positive ATT toward buying green products (Patel et al., 2020), since they believe that their actions are decisive for environmental well-being. In this vein, this study assumes that this positive effect 
will also occur in the context of LPF, since individuals will tend to believe that their behavioral actions are positive for the production of local food products. Thus, this study proposes the following hypothesis:

H9. INLOC has a direct and positive effect on the ATT toward the consumption of LPF.
Perceived risk of COVID-19 on consumers

\subsection{Locavorism}

Locavorism has been defined as a shared set of beliefs in which people reject industrial agriculture and actively consume LPF (Fitzgerald, 2016), and has been considered an emergent consumer ideology (Reich et al., 2018). This definition differentiates people with a locavore mindset from those with an organic mindset. The consumer of LPF shares health and environmental concerns with consumers of organic foods, but they differ in that the former only chooses LPF, while the latter consumes products from any source, including those of an international origin (Rana and Paul, 2017). Individuals with a locavore mindset believe that LPF promotes the local economy, besides tasting better, being healthier and being more environmentally friendly, since it does not have to travel long distances from the place of production to the final consumer (Scharber and Dances, 2016). This change in mentality of some consumers in Western countries arises as a consequence of some unpleasant results of agricultural industrialization, such as environmental degradation, incidents caused by foodborne diseases, declining food quality and negative economic impacts among local food producers (Reich et al., 2018). The emergence and development of a locavore mentality among consumers have facilitated the reappearance and/or the creation of farm direct sales, farmers' markets and coop stores that sell LPF, especially in Europe, which has a long historical tradition of fresh food markets (Spielmann and Bernelin, 2015).

Reich et al. (2018) developed and validated a multidimensional construct formed by the dimensions of lionization, opposition and communalization. Lionization is associated with the belief that local foods have a superior taste and quality. Opposition refers to opposition to food that has not been produced locally and to reliance on local food, as they believe that local food is safer and more transparent in terms of its traceability. Communalization refers to a satisfying sense of building and supporting local communities.

Several studies have partially analyzed the relationship between beliefs that could be described as locavorism and attitudes toward LPF. Thus, individuals consume local products because they are convinced that they favor the economic development of local communities and that the production systems are safer, more transparent (Meyerding et al., 2019) and more sustainable (Schmitt et al., 2017). Although research on locavorism is not abundant, some recent studies have found evidence showing that an attraction to the locavore stance positively influences consumers' attitudes when buying local foods in countries like China and Denmark (Zhang et al., 2020).

Therefore, and given the literature discussed above, consumers with a locavore mindset are likely to have a positive ATT toward LPF. Accordingly, the following hypothesis is proposed:

H10. Locavorism has a direct and positive effect on a favorable ATT toward the consumption of LPF.

\subsection{Perceived risk of COVID-19}

In the consumption context, perceived risk can be defined as a subjective perception regarding the uncertainty and negative consequences of the purchase of a product (Hussain et al., 2017). In this study, the uncertainty is due to the perceived risk from the COVID-19 pandemic. In the case of a pandemic, the perception of risk could be based on objective data, such as the number of people infected and deaths, but even more on the 
$\mathrm{BFJ}$

123,13

subjectivity of individuals due to the uncertainty, anxiety and fear produced by the difficulties in controlling the pandemic and its serious consequences (Yildirim and Güler, 2020).

Numerous studies have used the psychometric paradigm to explain the risk perception of hazards (Bonnet et al., 2012), which consists of two dimensions to assess risk perception in such situations: unknown risk and dread risk (Jenkins et al., 2021). With the aim of avoiding ambiguities, researchers have reframed these dimensions as cognitive and emotional/ affective (Yildirim and Güler, 2020). The cognitive dimension of risk perception is related to the probability and severity of the outcome, given the available information on the consequences of a risk. The emotional dimension contributes to the feeling of concern that a person has about a risk (Bonnet et al., 2012). Yildirim and Güler (2020) were the first to develop a COVID-19 perceived risk scale (CPRS) based on an adaptation of the SARS risk scale (Brug et al., 2004). This scale is made up of cognitive and emotional dimensions, which made it very suitable for use in this study. As a consequence, perceived risk of COVID-19 was defined as the individuals' risk perception, both cognitive and emotional, regarding the pandemic.

Previous research has shown that health awareness positively influences an individual's attitude toward healthier products, such as in the consumption of organic foods (Kim, 2019; Singh and Verma, 2017), functional foods (Xin and Seo, 2020) and products that have proven their health values (Mai and Hoffman, 2015). Consequently, if a concern for health exerts a positive influence on the attitude toward healthier food products, a similar effect should extend from the CPRS to the attitude toward LPF, as well as to the individuals' locavorism. Accordingly, this study proposes the following hypotheses:

H11. CPRS has a direct and positive effect on individuals' locavorism.

H12. CPRS has a direct and positive effect on ATT toward LPF.

Figure 1 summarizes the hypothesized relationships between variables of the conceptual model.

\section{Research methodology}

\subsection{Data source and measurement scale}

A questionnaire was used to collect empirical data with which to test the hypotheses proposed in the study. The questionnaire comprised 40 questions and two sections. The first section included 37 items to measure the conceptual model (see Table A1). These 37 items were measured on a seven-point Likert scale. The second section included general sociodemographic characteristics. The items of the questionnaire were adapted from previous studies in the literature.

Purchase intention toward LPF was measured with three items from the study by Bianchi and Mortimer (2015). To measure SWI toward LPF, three items were adapted from the study by Wu et al. (2018). Other TPB variables were measured from studies on organic and local foods. Three items from Rahimah et al. (2018), four items from Bianchi and Mortimer (2015) and three items from Dean et al. (2012) were adapted to measure ATT, SN and PBC, respectively. INLOC was measured with three items adapted from the study by Cleveland et al. (2005). Locavorism was measured with the three dimensions from Reich et al. (2018): lionization with three items, opposition with four items and communalization with four items. Finally, perceived risk of COVID-19 was measured with the cognitive and emotional dimensions taken from the scale by Yildirim and Güler (2020), using four items from each of them.

The questionnaire was translated from English into Spanish and then back-translated to check the validity of the translation. Finally, the instrument was pretested with research 


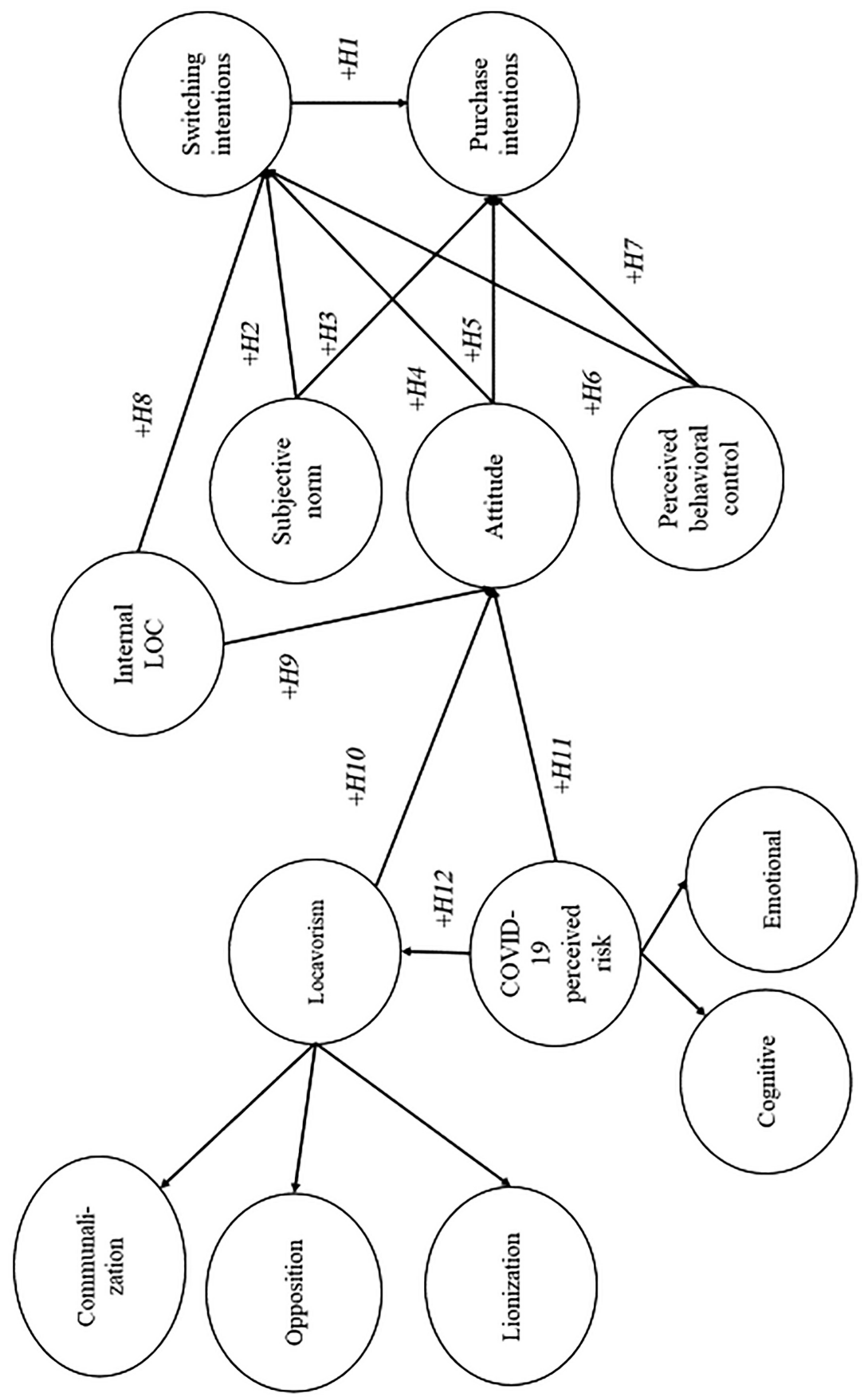

Perceived risk of COVID-19 on consumers

287

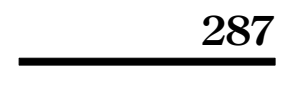

Figure 1. Conceptual research framework 
BFJ

123,13 experts and professional food experts. As a result, minor adjustments were made to make it more understandable, consistent, relevant and to avoid ambiguity.

\subsection{Data collection procedure}

Netquest (https://www.netquest.com), an online research panel with more than 1,300,000 panelists in 23 countries around the world, was used to collect responses from consumers of the five major cities in Spain. Netquest meets ISO 26362:2009 requirements and follows the national data protection regulation of the countries in which it operates. In addition, it complies with ESOMAR (European Society for Opinion and Market Research) standards for conducting online research. The cities were chosen due to the fact that major urban areas were most affected by the pandemic in terms of cases per inhabitant, as well as economic consequences. For instance, the big Spanish cities published a joint statement on April 14, 2020 , in which they explained that due to population concentration and density they were the most affected by the repercussions of the COVID-19 crisis, and consequently demanded capacities and resources from the Spanish government to help face it (Barcelona City Council, 2020).

Individuals in the sample were recruited from the inhabitants of the five main cities in Spain among the general Netquest panel members and the panelists received an email invitation to take part in an online survey. The quotas were designed according to the proportion of inhabitants in these five cities, as follows: Madrid (46.3\%), Barcelona $(23.2 \%)$, Valencia $(11.2 \%)$, Sevilla $(9.7 \%)$ and Zaragoza $(9.6 \%)$. The panel provider ensured representativeness of the sample for the following dimensions: city, gender and an age range between 30 and 59 years. The survey was administered online between September 28 and October 1, 2020, during the second wave of the COVID-19 pandemic in Spain. Participants received redeemable points for a completed survey, which could be accumulated with other studies, or immediately exchanged for a small gift.

\subsection{Statistical analyses}

The proposed model and the underlying hypotheses were estimated with partial least squares structural equation modeling (PLS-SEM) path modeling with SmartPLS 3.2. PLSSEM was chosen based on the following considerations. First, the nature of the latent variables is more compatible with a composite structure than with pure common factor models. PLS-SEM estimates the latent variables as composites. Composites use linear combinations of indicators as proxies of the conceptual variables under investigation to explain the variance of the unobserved variables. These composites can be estimated either as reflective composites, or mode $\mathrm{A}$, when indicators and the construct are expected to be highly correlated, or as formative composites, or mode B, when indicators are expected to be combined to shape the construct and are not necessarily correlated (Cepeda-Carrion et al., 2019). The model includes some constructs with a composite reflective structure (also known as mode A composites) (i.e. behavioral intentions or attitudes) and others with a composite formative construct structure (also known as mode B composites) (i.e. the dimensions of the perceived risk of COVID-19). Second, the study presents a mixed approach, since its main goal is predictive-explanatory, which fits the domain of PLS-SEM (Henseler, 2018). Third, the model is complex, includes a great number of latent and manifest variables, and presents many relationships among the latent constructs in the form of direct and indirect effects (Cepeda-Carrion et al., 2019). Fourth, this complexity is accentuated by the incorporation of first-order latent variables and second-order (multidimensional) variables (Henseler et al., 2016). Fifth, the research topic is novel and combines different theoretical views, but is still lacking with regard to theoretical development. The concept of locavorism has, for example, only recently been advocated as a critical variable in explaining sustainable consumption and 
still lacks empirical confirmation. In addition, to our knowledge, no study has explored the role of the perceived risk of COVID-19 in explaining locavorism and attitudes toward local products. Table 1 summarizes the measurement models of the variables included in the study.

The application of the PLS-SEM technique requires the estimation of the measurement model as well as the structural model. In the measurement model, the reflective mode A constructs were assessed in terms of their individual (items' outer loadings) and composite reliability (composite reliability index and Jöreskog's Rho), convergent validity (Average Variance Extracted, (AVE) and discriminant validity (Heterotrait-Monotrait (HTMT) ratios approach). For the formative mode B constructs, collinearity between the formative indicators was examined through the variance inflation factor (VIF). Also, the sign, magnitude and statistical significance of the weights of their indicators were assessed. In the structural model, potential collinearity issues among latent constructs were examined by evaluating its VIF values. The predictive power and relevance of the model were also analyzed (Shmueli et al., 2019). To do so, we examined the Stone-Geisser's $Q^{2}$ values, which represent an assessment criterion for the model's cross-validated predictive relevance of the model, the root mean squared error (RMSE) of the final dependent variable in the estimated model and in a naïve benchmark model, and the $R^{2}$ of the dependent variables. Since the causality of the variables is pre-determined, the significance of the structural parameters was calculated with a one-tailed bootstrapping test with 10,000 subsamples. The level of statistical significance was set at $5 \%$. The bootstrapped percentile confidence intervals were also examined to establish the significance of the structural parameters (Aguirre-Urreta and Rönkkö, 2018). The two-stage approach was applied to estimate both second-order constructs (Sarstedt et al., 2019).

\section{Results}

\subsection{Characteristics of the sample}

A total of 1,005 consumers participated in the study, $53 \%$ of whom were women. Ages ranged from 30 to 59 years, with an average of 43.2. The majority of respondents were employed $(72.7 \%)$, and most of them $(55.2 \%)$ had a monthly income in the $€ 1,001$ to $€ 3,500$ bracket.

\subsection{Assessment of the measurement model}

The first-order factors from both multidimensional constructs presented individual and composite reliability as well as convergent and discriminant validity. All factorial loadings

\begin{tabular}{|c|c|c|c|}
\hline$\underline{\text { First-order latent variables }}$ & $\begin{array}{l}\text { First-order } \\
\text { measurement model }\end{array}$ & $\begin{array}{l}\text { Second-order latent } \\
\text { variables }\end{array}$ & $\begin{array}{l}\text { Second-order } \\
\text { measurement model }\end{array}$ \\
\hline Cognitive risk (COG) & Composite mode A & COVID-19 perceived & Composite mode B \\
\hline Emotional risk (EMO) & Composite mode A & risk & \\
\hline Lionization (LIO) & Composite mode A & Locavorism & Composite mode A \\
\hline Opposition (OPP) & Composite mode A & & \\
\hline Communalization (COM) & Composite mode A & & \\
\hline $\begin{array}{l}\text { Internal locus of control } \\
\text { (INLOC) }\end{array}$ & Composite mode A & $\mathrm{n} / \mathrm{a}$ & $\mathrm{n} / \mathrm{a}$ \\
\hline $\begin{array}{l}\text { Perceived behavioral } \\
\text { control (PBC) }\end{array}$ & Composite mode $\mathrm{A}$ & & \\
\hline Attitude (ATT) & Composite mode A & $\mathrm{n} / \mathrm{a}$ & $\mathrm{n} / \mathrm{a}$ \\
\hline Subjective norm (SN) & Composite mode $\mathrm{A}$ & & \\
\hline Switching intentions (SWI) & Composite mode A & $\mathrm{n} / \mathrm{a}$ & $\mathrm{n} / \mathrm{a}$ \\
\hline Purchase intentions (PUR) & Composite mode A & $\mathrm{n} / \mathrm{a}$ & $\mathrm{n} / \mathrm{a}$ \\
\hline
\end{tabular}

Perceived risk of COVID-19 on consumers

289 
BFJ 123,13

290

were above 0.708 , which guaranteed the individual reliability of the items (Hair et al., 2019), and the composite reliability index and the Rho_A (Dijkstra and Henseler, 2015) were both above the critical cut-off points of 0.7. The AVE metric was above $50 \%$, which guarantees convergent validity (Hair et al., 2017). Finally, discriminant validity was examined through the HTMT ratios approach (Henseler et al., 2015). All the HTMT values among the reflective constructs were below the critical threshold of 0.85 , thereby demonstrating the existence of discriminant validity. For the formative construct, the variance inflation factor (VIF) of the indicators was below the critical threshold of 3.3. The cognitive dimensions of risk perception presented a significant weight of $0.305(\phi<0.05)$ and the emotional risk had a weight of 0.793 $(p<0.05)$. Tables 2 and 3 summarize the assessment of the measurement model.

\subsection{Assessment of the structural model}

Regarding the structural model, multicollinearity among the independent variables is not a problem in this study, since all the VIF indicators were below the suggested threshold of 3.3 (Hair et al., 2019). All the $Q^{2}$ values (predictive relevance of the model) for the endogenous variables were positive, and predicted the endogenous latent constructs, as well the quality of the PLS path model. For the variable PUR, two of the RMSE of the PLS-SEM estimation of the three indicators were lower than the RMSE of the naïve linear model. In the case of SWI, both RMSE values were also below the naïve model. Consequently, it could be argued that the model presents adequate predictive power. Regarding the predictive relevance of the model, the $R^{2}$ of the final dependent variables (PUR, SWI and ATT) present high values above $33 \%$,

\begin{tabular}{|c|c|c|c|c|c|c|}
\hline $\begin{array}{l}\text { First-order } \\
\text { construct }\end{array}$ & Indicator & $\begin{array}{c}\text { Standardized } \\
\text { loading/Weight }\end{array}$ & Rho_A & $\begin{array}{l}\text { Composite } \\
\text { reliability } \\
\text { index (CRI) }\end{array}$ & $\begin{array}{l}\text { Average } \\
\text { variance } \\
\text { extracted } \\
\text { (AVE) }\end{array}$ & $\begin{array}{l}\text { Variance } \\
\text { inflation } \\
\text { factor (VIF) }\end{array}$ \\
\hline COVID-19 & $C O G$ & $0.305^{*}$ & \multirow[t]{2}{*}{$\mathrm{n} / \mathrm{a}$} & \multirow[t]{2}{*}{$\mathrm{n} / \mathrm{a}$} & \multirow[t]{2}{*}{$\mathrm{n} / \mathrm{a}$} & 1.495 \\
\hline $\begin{array}{l}\text { perceived risk } \\
\text { (CPRS) }\end{array}$ & $E M O$ & $0.793 *$ & & & & 1.495 \\
\hline LOCAV & $\begin{array}{l}L I O \\
O P P \\
C O M\end{array}$ & $\begin{array}{l}0.769 \\
0.697 \\
0.906\end{array}$ & 0.909 & 0.836 & 0.633 & $\mathrm{n} / \mathrm{a}$ \\
\hline INLOC & $\begin{array}{l}\text { ILC1 } \\
\text { ILC2 } \\
\text { ILC3 }\end{array}$ & $\begin{array}{l}0.866 \\
0.837 \\
0.903\end{array}$ & 0.863 & 0.902 & 0.755 & $\mathrm{n} / \mathrm{a}$ \\
\hline SN & $\begin{array}{l}\text { SN1 } \\
\text { SN2 } \\
\text { SN3 } \\
\text { SN4 }\end{array}$ & $\begin{array}{l}0.928 \\
0.912 \\
0.922 \\
0.769\end{array}$ & 0.908 & 0.935 & 0.783 & $\mathrm{n} / \mathrm{a}$ \\
\hline $\begin{array}{l}\text { Attitude } \\
\text { (ATT) }\end{array}$ & $\begin{array}{l}\text { ATT1 } \\
\text { ATT2 } \\
\text { ATT3 }\end{array}$ & $\begin{array}{l}0.936 \\
0.872 \\
0.932\end{array}$ & 0.912 & 0.938 & 0.835 & $\mathrm{n} / \mathrm{a}$ \\
\hline $\mathrm{PBC}$ & $\begin{array}{l}P B C 1 \\
P B C 2 \\
P B C 3\end{array}$ & $\begin{array}{l}0.907 \\
0.862 \\
0.804\end{array}$ & 0.862 & 0.894 & 0.738 & $\mathrm{n} / \mathrm{a}$ \\
\hline SWI & $\begin{array}{l}\text { SWI1 } \\
\text { SWI2 }\end{array}$ & $\begin{array}{l}0.971 \\
0.971\end{array}$ & 0.940 & 0.971 & 0.943 & $\mathrm{n} / \mathrm{a}$ \\
\hline PUR & $\begin{array}{l}\text { PUR1 } \\
\text { PUR2 } \\
\text { PUR2 }\end{array}$ & $\begin{array}{l}0.970 \\
0.974 \\
0.978\end{array}$ & 0.973 & 0.982 & 0.949 & $\mathrm{n} / \mathrm{a}$ \\
\hline $\operatorname{Note}(\mathbf{s}): *=$ & $<0.05)$ & & & & & \\
\hline
\end{tabular}

Table 2.

Measurement model Note(s): $*=(p<0.05)$ 
while the explained variance of locavorism is just 3.8\%. Table 4 shows the results of the estimation of the structural model (see Figure 2).

\subsection{Structural model results}

The estimation of the structural parameters revealed that SWI positively influenced consumers' intentions to purchase LPF $(\beta=0.567$; $t$-value $=20.508)$, SN was positively and significantly associated with SWI $(\beta=0.363 ; t$-value $=10.785)$ and PUR $(\beta=0.160$; $t$-value $=5.783$ ), thus confirming H1 to H3. ATT positively and significantly influenced both $\operatorname{SWI}(\beta=0.221 ; t$-value $=7.810)$ and PUR $(\beta=0.251 ; t$-value $=10.236)$, supporting $\mathrm{H} 4$ and $\mathrm{H} 5$. However, PBC did not exert a significant effect on SWI $(\beta=-0.014$; $t$-value $=0.359)$, and significantly reduced consumers' intentions to purchase LPF $(\beta=-0.035 ; t$-value $=1.684)$. These results lead us to reject $\mathrm{H} 6$ and $\mathrm{H} 7$. The INLOC was also found to positively and significantly predict SWI $(\beta=0.224 ; t$-value $=6.755)$ and ATT $(\beta=0.304 ; t$-value $=9.830)$, thus confirming $\mathrm{H} 8$ and $\mathrm{H} 9$. Locavorism was revealed to positively and significantly influence consumers' ATT toward LPF $(\beta=0.416$; $t$-value $=11.395)$. In addition, consumers with higher CPRS showed a better ATT toward LPF $(\beta=0.085$; $t$-value $=2.643)$ and also presented higher levels of locavorism $(\beta=0.191 ; t$-value $=5.267)$. These findings confirm H10 to H12.

\begin{tabular}{lcccccccc}
\hline Construct & 1 & 2 & 3 & 4 & 5 & 6 & 7 & 8 \\
\hline 1. CPRS & n/a & n/a & n/a & n/a & n/a & n/a & n/a & n/a \\
2. LOCAV & 0.191 & 0.795 & 0.586 & 0.642 & 0.578 & 0.159 & 0.728 & 0.710 \\
3. INLOC & 0.119 & 0.478 & 0.869 & 0.594 & 0.481 & 0.073 & 0.654 & 0.608 \\
4. SN & 0.224 & 0.542 & 0.523 & 0.885 & 0.517 & 0.031 & 0.679 & 0.676 \\
5. ATT & 0.189 & 0.531 & 0.429 & 0.468 & 0.914 & 0.033 & 0.563 & 0.661 \\
6. PBC & 0.071 & 0.108 & 0.058 & -0.017 & 0.015 & 0.859 & 0.021 & 0.037 \\
7. SWI & 0.106 & 0.622 & 0.588 & 0.626 & 0.521 & 0.001 & 0.971 & 0.835 \\
8. PUR & 0.144 & 0.643 & 0.559 & 0.634 & 0.621 & -0.034 & 0.798 & 0.974
\end{tabular}

Note(s): Figures on the diagonal represent the AVE values. Figures below the diagonal represent the squared correlations of the constructs. Figures above the diagonal represent the HTMT ratios
Perceived risk of COVID-19 on consumers

Table 3. Discriminant validity of the measurement model - HTMT ratio

\begin{tabular}{lcccr}
\hline Hypothesis & $\beta$ & $t$-value & PCI (5\%) & PCI (95\%) \\
\hline (H1) SWI $\rightarrow$ PUR & 0.567 & $20.508^{*}$ & 0.521 & 0.612 \\
(H2) SN $\rightarrow$ SWI & 0.363 & $10.785^{*}$ & 0.308 & 0.418 \\
(H3) SN $\rightarrow$ PUR & 0.160 & $5.783^{*}$ & 0.114 & 0.206 \\
(H4) Attitude $\rightarrow$ SWI & 0.221 & $7.810^{*}$ & 0.175 & 0.267 \\
H5) Attitude $\rightarrow$ PUR & 0.251 & $10.236^{*}$ & 0.211 & 0.292 \\
(H6) PBC $\rightarrow$ SWI & -0.014 & 0.359 & -0.069 & 0.054 \\
(H7) PBC $\rightarrow$ PUR & -0.035 & $1.684^{* *}$ & -0.067 & -0.001 \\
(H8) INLOC $\rightarrow$ SWI & 0.304 & $9.830^{*}$ & 0.253 & 0.354 \\
(H9) INLOC $\rightarrow$ Attitude & 0.224 & $6.755^{*}$ & 0.170 & 0.278 \\
(H10) Locavorism $\rightarrow$ Attitude & 0.416 & $11.395^{*}$ & 0.349 & 0.466 \\
(H11) CPRS $\rightarrow$ Attitude & 0.085 & $2.643^{*}$ & 0.034 & 0.139 \\
(H12) CPRS $\rightarrow$ Locavorism & 0.191 & $5.267^{*}$ & 0.135 & 0.254
\end{tabular}

Note(s): $R^{2-\mathrm{PUR}}=0.715 ; \mathrm{R}^{2-\mathrm{SWI}}=0.521 ; R^{2-} \mathrm{ATT}=0.331 ; R^{2-}$ Locavorism $=0.038$

Table 4.

Results of the structural model 
BFJ

123,13

292

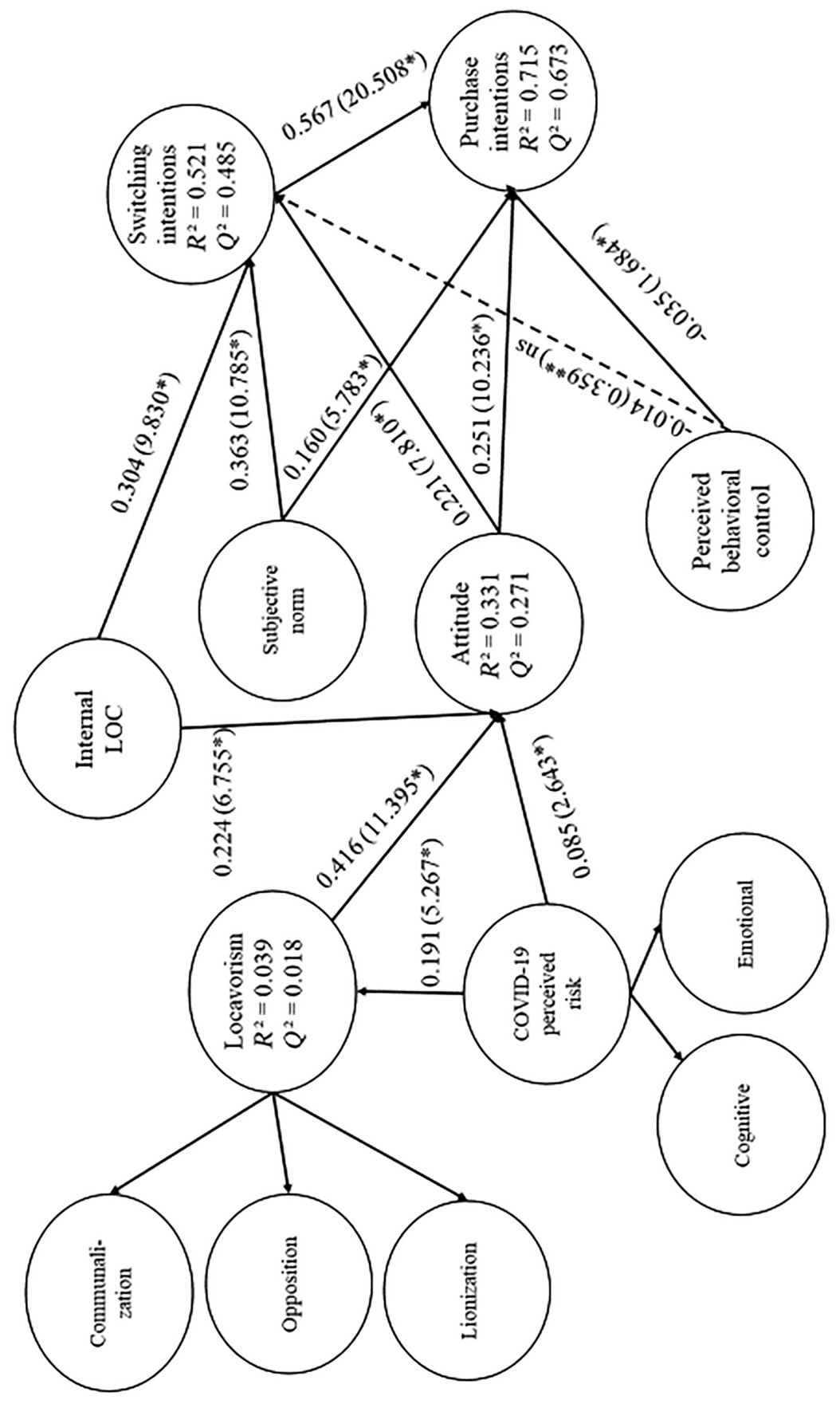

Figure 2. 


\section{Discussion}

This study sought to understand how the predisposition of consumers toward LPF works in a period of risk due to the threat produced by COVID-19. To do so, an extension of the TPB was performed, adding CPRS, locavorism and INLOC, in order to increase the estimation power of TPB, and to make more meaningful theoretical contributions to the food marketing literature during the COVID-19 pandemic. The results showed that perceived risk of COVID19 predicts locavorism and ATT toward LPF; INLOC predicts attitude and SWI; SN and ATT have a positive influence on SWI and PUR; and PBC negatively influences PUR. The most noteworthy outcome of this new model is the inclusion of the CPRS, locavorism, INLOC and switching intentions, which turned out to be influential on intentional LPF purchasing behavior.

This study provides a more comprehensive view of the impact of the COVID-19 pandemic on consumers' attitudes and behavior. The risk of infection and the possibility of having the disease led individuals to be more inclined toward locavorism, which in turn has a strong impact on developing a positive ATT toward LPF (Zhang et al., 2020). Consistent with previous studies on health awareness, the results showed that when individuals are concerned about their health, the ATT toward local food products increases positively (Singh and Verma, 2017). However, in the context of the COVID-19 pandemic, this study shows that this relationship is mediated by feelings of locavorism. One possible interpretation of these results is that this pandemic has had various lockdowns, restrictions and perimeter closures at the national and regional levels. These restrictions interrupted the international movement of goods and broke long supply chains, while shorter and more local supply chains felt these restrictions to a lesser extent, and they were closer to the consumers (Capelli and Cini, 2020). It is very likely that these events have favored the increase in locavorism among consumers in large Spanish cities, since international data confirm the increase in the consumption of LPF (Nielsen, 2020). Consequently, the risk of being infected with COVID-19 becomes a predictor of feelings of locavorism, since these consumers are more convinced that local foods have a better flavor, prefer products that have been produced locally, and support local communities both socially and economically (Reich et al., 2018), which is a contribution of this research. In fact, this would agree with the conclusions reported by Rodríguez-Perez et al. (2020) in a study carried out among the Spanish population during the first wave of the virus and the first lockdown (March-April 2020). These authors identified an increase in consumption of the Mediterranean diet (MedDiet), which is considered a reference as regards healthy eating made up mostly of a very high percentage of olive oil, fruits, vegetables and legumes, which are usually LPF. However, the predictive power of CPRS on locavorism is low, as is reflected in the $R^{2}$. This finding exhibits that locavorism is not explained only by the perceived risk of COVID-19. In fact, other independent variables could also explain locavorism, such as personal values, long-term orientation (Zhang et al., 2020), political ideology, ethnocentrism, as well as other social, developmental systemic factors that remain unexplored (Reich et al., 2018).

The results of INLOC reinforce its importance as a significant determinant of ATT and SWI. INLOC has a positive effect on ATT, confirming the findings of Patel et al. (2020) for green products. The strong positive relationship between INLOC and SWI is an important contribution of this study, highlighting the fact that consumers' INLOC will encourage them to seek economic resources to change from a conventional brand to a local one, thus supporting LPF, even if they need to spend more to purchase these products.

Regarding the TPB, the findings are consistent with previous research except for PBC. The results of ATT reveal that it has a decisive effect on the intention to perform an action. These findings are also in line with past research on the consumption of local food products (Bavorava et al., 2018; Bianchi and Mortimer, 2015; Vabø and Hansen, 2016), in which researchers have identified the influence of ATT toward PUR, confirming that the more
Perceived risk of COVID-19 on consumers 
BFJ

123,13

positive the ATT is, the stronger the PUR will be. Additionally, this study has shown the positive influence of ATT on SWI, which is not usual in TPB studies.

Consistent with the expectations of this study, SN has been found to be an important predictor of SWI and PUR, indicating social pressure from reference groups on individuals so that they switch from conventional food brands to LPF vendors. Indeed, SN has been found to be the most powerful factor leading consumers to make such a switch in the source of their food products. This positive influence of SN on SWI, verified in other contexts such as technology (Sun et al., 2017), is not common in TPB studies, which is why it represents a novelty in this research. In addition, the positive impact of SN on PUR is already the consequence of the social pressure to perform that behavior, which has been identified previously among consumers in short food supply chains (Giampietri et al., 2016).

Contrary to the expectations of this study, $\mathrm{PBC}$ is not a significant predictor of SWI, and it is a negative predictor of PUR, suggesting that the intention to purchase LPF is not under the volitional control of the consumers (Ajzen, 1991,2015). This unexpected negative relationship is consistent with the findings of Asif et al. (2018) in the context of organic food. A possible explanation is that the offer of LPF is low compared to other conventional food brands, and this acts as a barrier. In fact, previous literature has identified several barriers to purchasing $\mathrm{LPF}$, such as the effort required to pay higher prices, the availability of the product and lack of time (Bianchi and Mortimer, 2015). Individuals probably perceive that they have difficulties to purchase LPF due to the additional effort they have to make and because of the lack of availability at the points of sale that they usually use in large cities.

\section{Implications, limitations and future research}

The impact of the pandemic crisis, like all global uncertainty crises, has had unexpected consequences in a world characterized by volatility, uncertainty, complexity and ambiguity (VUCA) (Giones et al., 2019). Lockdown, social distancing, mobility restrictions and location shortage (Sheth, 2020) are some of the consequences that have affected the world economy. Future global crises, such as other pandemics, natural disasters or climate crises, could give rise to these problems again. This research has shown that in situations of uncertainty, consumers support locally produced food; that is to say, the short chains of local production that are always less affected by restrictions on international trade in situations of global crisis, and are more rooted in the territory and closer to the consumer. For these reasons, it is crucial that policymakers support and improve short food supply chains and local production (Capelli and Cini, 2020). As a consequence, the results of this study have implications for policymakers. One of its most relevant findings is that the COVID-19 pandemic has made citizens of large Spanish cities more closely aligned with locavorism and, consequently, more likely to consume LPF, although there are some difficulties regarding its availability. In addition, the sales of most of these small producers, mainly small and medium-sized enterprises (SMEs) or micro-businesses, fell to zero with the closure of their most powerful clients, such as hotels and restaurants, and they were unable to connect with consumers in large cities due to the geographical distance or because they had never sold in those market segments (OECD, 2021). Consequently, policymakers should promote public policies that facilitate the direct relationship between local producers and consumers in large cities, so that they can diversify their market segments. For example, initiatives could include support for the digitalization of businesses, the development of online platforms in which a market of supply and demand can be set up, and the creation of logistics systems that allow the daily delivery of fresh products and ensure the availability of the product at the points of sale and/ or for home delivery. These public policies could satisfy the needs of citizens, who are demanding these products, solve the problem of connection between local producers and 
consumers in large cities and, consequently, create far more wealth in the economy where local food producers carry out their activity.

SMEs and micro-businesses could seek the support of county councils and city councils to develop joint promotional activities, through webinars and social networks. Such activities could connect them with consumers who are increasingly more inclined toward the locavore movement. They could also allow them to reinforce the message of better tasting, fresher and healthier products, as well as the environmentally friendly and wellness-creating benefits of their activities.

This study has some limitations. First, it was carried out in a context of mobility restrictions and physical social distance, which did not allow face-to-face data collection and meant it had to be carried out through an online panel. The data must therefore be treated with caution. Future research, once the pandemic is over, could collect data face-to-face and improve the validity of the results. Second, the sample of this study was limited to residents of large Spanish cities, and therefore the results of this study should be generalized with caution. Consequently, it is recommended that future research should examine samples in other large European cities. Third, the perceived risk of COVID-19 accounts for only 3.8\% of the locavorism variance. This indicates that some important factors are not being included in the research model. For example, personal circumstances during the pandemic, personal values or political orientation may play important roles in explaining locavorism. Consequently, future research could add these variables to the current model.

\section{References}

Aguirre-Urreta, M.I. and Rönkkö, M. (2018), "Statistical inference with PLSc using bootstrap confidence intervals", MIS Quarterly, Vol. 42 No. 3, pp. 1001-1020.

Ajzen, I. (1991), "The theory of planned behavior", Organizational Behavior and Human Decision Processes, Vol. 50 No. 2, pp. 179-211.

Ajzen, I. (2002), "Perceived behavioral control, self-efficacy, locus of control, and the theory of planned behavior", Journal of Applied Social Psychology, Vol. 32 No. 4, pp. 665-668.

Ajzen, I. (2015), "Consumer attitudes and behavior: the theory of planned behavior applied to food consumption decisions", Rivista di Economia Agraria, Vol. 70 No. 2, pp. 121-138.

Asif, M., Xuhui, W., Nasiri, A. and Ayyub, S. (2018), "Determinant factors influencing organic food purchase intention and the moderating role of awareness: a comparative analysis", Food Quality and Preference, Vol. 63, pp. 144-150.

Barcelona City Council (2020), Las grandes ciudades solicitan al Estado flexibilidad para dedicar recursos a hacer frente a la COVID-19, available at: https:/ajuntament.barcelona.cat/ pactedeltemps/es/noticia/las-grandes-ciudad-piden-en-el-estado-flexibilidad-para-dedicarrecursos-a-hacer-frente-a-la-covid-19_938373 (accessed 31 May 2021).

Basha, M.B. and Lal, D. (2018), "Indian consumers' attitudes towards purchasing organically produced foods: an empirical study", Journal of Cleaner Production, Vol. 215 No. 1, pp. 99-111.

Bavorava, M., Traikova, D. and Doms, J. (2018), "Who are the farm shop buyers? A case study in Naumburg, Germany”, British Food Journal, Vol. 120 No. 2, pp. 255-268.

Bianchi, C. and Mortimer, G. (2015), "Drivers of local food consumption: a comparative study", British Food Journal, Vol. 117 No. 9, pp. 2282-2299.

Bonnet, E., Amalric, M., Chevéc, M. and Travers, M. (2012), "Hazard and living environment: combining industrial risk and landscape representations", Journal of Risk Research, Vol. 15 No. 10, pp. 1281-1298.

Boobalan, K. and Nachimuthu, G.S. (2020), "Organic consumerism: a comparison between India and the USA", Journal of Retailing and Consumer Services, Vol. 53. doi: 10.1016/j.jretconser.2019. 101988.
Perceived risk of COVID-19 on consumers 
BFJ 123,13

Bradley, G.L. and Sparks, B.A. (2002), "Service locus of control. Its conceptualization and measurement", Journal of Service Research, Vol. 4 No. 4, pp. 312-324.

Brug, J., Aro, A.R., Oenema, A., de Zwart, O., Richardus, J.H. and Bishop, G.D. (2004), "SARS risk perception, knowledge, precautions, and information sources, The Netherlands", Emerging Infectious Diseases, Vol. 10 No. 8, pp. 1486-1489.

Brune, S., Knollenberg, W., Stevenson, K.T., Barbieri, C. and Schroeder-Moreno, M. (2020), "The influence of agritourism experiences on consumer behavior toward local food", Journal of Travel Research. doi: 10.1177/0047287520938869.

Bryla, P. (2016), "Organic food consumption in Poland: motives and barriers", Appetite, Vol. 105 No. 1, pp. 737-746.

Capelli, A. and Cini, E. (2020), "Will the COVID-19 pandemic make us reconsider the relevance of short food supply chains and local productions?", Trends in Food Science and Technology. doi: 10. 1016/j.tifs.2020.03.041.

Cepeda-Carrion, G., Cegarra-Navarro, J.G. and Cillo, V. (2019), "Tips to use partial least squares structural equation modelling (PLS-SEM) in knowledge management", Journal of Knowledge Management, Vol. 23 No. 1, pp. 67-89.

Cho, Y.C. and Song, J. (2012), "The effects of customer dissatisfaction on switching behavior in the service sector", Journal of Business and Economics Research, Vol. 10 No. 10, pp. 579-592.

Cleveland, M., Kalamas, M. and Laroche, M. (2005), "Shades of green:linking environmental locus of control and pro-environmental behaviors", Journal of Consumer Marketing, Vol. 22 No. 4, pp. 198-212.

Cleveland, M., Robertson, J.L. and Volk, V. (2020), "Helping or hindering: environmental locus of control, subjective enablers and constraints, and pro-environmental behaviors", Journal of Cleaner Production, Vol. 249, 119394, doi: 10.1016/j.jclepro.2019.119394.

Cummins, S., Berger, N., Cornelsen, L., Eling, J., Er, V., Greener, R., Kalbus, A., Karapici, A., Law, C., Ndlovu, D. and Yau, A. (2020), "COVID-19: impact on the urban food retail system and dietary inequalities in the UK", Cities and Health. doi: 10.1080/23748834.2020.1785167.

Dean, M., Raats, M.M. and Shepherd, R. (2012), "The role of self-identity, past behavior, and their Interaction in predicting intention to purchase fresh and processed organic food", Journal of Applied Social Psychology, Vol. 42 No. 3, pp. 669-688.

Dijkstra, T.K. and Henseler, J. (2015), “Consistent partial least squares path modeling”, MIS Quarterly, Vol. 39 No. 2, pp. 297-316.

Farah, M.F. (2017), "Application of the theory of planned behavior to customer switching intentions in the context of bank consolidations", International Journal of Bank Marketing, Vol. 35 No. 1, pp. 147-172.

Fiandari, Y.R., Surachman, S., Rohman, F. and Hussein, A.S. (2019), "Perceived value dimension in repetitive fish consumption in Indonesia by using an extended theory of planned behavior", British Food Journal, Vol. 121 No. 6, pp. 1220-1235.

Fitzgerald, K.J. (2016), "Thinking globally, acting locally: locavorism and humanist sociology", Humanity and Society, Vol. 40 No. 1, pp. 3-21.

Giampietri, E., Finco, A. and Del Giudice, T. (2016), "Exploring consumers' behaviour towards short food supply chains", British Food Journal, Vol. 118 No. 3, pp. 618-631.

Giones, F., Brem, A. and Berger, A. (2019), "Strategic decisions in turbulent times: lessons from the energy industry", Business Horizons, Vol. 62 No. 2, pp. 215-225.

Hair, J.F., Hult, G.T.M., Ringle, C.M. and Sarstedt, M. (2017), A Primer on Partial Least Squares Structural Equation Modeling (PLS-SEM), 2nd ed., Sage, Thousand Oaks.

Hair, J.F., Risher, J.J., Sarstedt, M. and Ringle, C.M. (2019), "When to use and how to report the results of PLS-SEM", European Business Review, Vol. 31 No. 1, pp. 2-24.

Han, H., Kim, W. and Hyun, S.S. (2011), "Switching intention model development: role of service performances, customer satisfaction, and switching barriers in the hotel industry", International Journal of Hospitality Management, Vol. 30 No. 3, pp. 619-629. 
Hassan, L.M., Shiu, E. and Parry, S. (2016), "Addressing the cross-country applicability of the theory of planned behaviour (TPB): a structured review of multi-country TPB studies", Journal of Consumer Behaviour, Vol. 15 No. 1, pp. 72-86.

He, Q., Duan, Y., Wang, R. and Fu, Z. (2019), "Factors affecting consumers' purchase intention of ecofriendly food in China: the evidence from respondents in Beijing", International Journal of Consumer Studies, Vol. 43 No. 5, pp. 457-470.

Henseler, J. (2018), "Partial least squares path modeling: quo vadis?”, Quality and Quantity, Vol. 52 No. 1 , pp. 1-8.

Henseler, J., Ringle, C.M. and Sarstedt, M. (2015), "A new criterion for assessing discriminant validity in variance-based structural equation modeling", Journal of the Academy of Marketing Science, Vol. 43 No. 1, pp. 115-135.

Henseler, J., Hubona, G. and Ray, P.A. (2016), "Using PLS path modeling in new technology research: updated guidelines", Industrial Management and Data Systems, Vol. 116 No. 1, pp. 2-20.

Hino, H. (2017), "Does switching-intention result in a change in behaviour? Exploring the actual behavioural shopping patterns of switching-intended customers", British Food Journal, Vol. 119 No. 12 , pp. 2903-2917.

Hussain, S., Ahmed, W., Jafar, R.M.S., Rabnawaz, A. and Jianzhou, Y. (2017), "eWOM source credibility, perceived risk and food product customer's information adoption", Computers in Human Behavior, Vol. 66, pp. 96-102.

Hwang, J., Lee, J.-S., Kim, J.J. and Sial, M.S. (2020), "Application of internal environmental locus of control to the context of eco-friendly drone food delivery services", Journal of Sustainable Tourism. doi: 10.1080/09669582.2020.1775237.

Jenkins, S.C., Harris, A.J.L. and Osman, M. (2021), "What drives risk perceptions? Revisiting public perceptions of food hazards associated with production and consumption", Journal of Risk Research. doi: 10.1080/13669877.2020.1871057.

Kantar (2020), State of Alert n Spain Triggers FMCG Shopping, available at: https://www.kantar.com/ Inspiration/Coronavirus/Food-expenditure-continues-to-spike-in-Spain-due-to-coronavirus? utmsource $=$ Kantar + Worldpanel + global + newsletter\&utm_campaign $=1016624 \mathrm{~d} 4 \mathrm{f}-\mathrm{EMAIL}$ CAMPAIGN_2020_03_30_09_22\&utm_medium =email\&utm_term=0_6f20cf9a58-1016624d4f118992365 (accessed January 6, 2021).

Khan, F. and Prior, C. (2010), "Evaluating the urban consumer with regard to sourcing local food: a heart of England study", International Journal of Consumer Studies, Vol. 34 No. 2, pp. 161-168.

Kim, Y.-H. (2019), "Organic shoppers' involvement in organic foods: self and identity", British Food Journal, Vol. 121 No. 1, pp. 139-156.

La Vanguardia, L. (2020), "E-commerce y producto local: la fórmula del éxito anti-covid para la España vaciada", available at: https://www.lavanguardia.com/economia/20200510/ 481011400482/ecommerce-producto-local-formula-exito-anti-covid19-espana-vaciada-correosbrl.html (accessed 6 January 2021).

Mai, R. and Hoffmann, S. (2015), "How to combat the unhealthy = Taste intuition: the influencing role of health consciousness", Journal of Public Health and Policy, Vol. 34 No. 1, pp. 63-83.

Marty, L., de Lauzon-Guillain, B., Labesse, M. and Nicklaus, S. (2020), "Food choice motives and the nutritional quality of diet during the COVID-19 lockdown in France", Appetite, Vol. 157, doi: 10. 1016/j.appet.2020.105005.

Meyerding, S.G., Trajer, N. and Lehberger, M. (2019), "What is local food? The case of consumer preferences for local food labeling of tomatoes in Germany", Journal of Cleaner Production, Vol. 207 No. 10, pp. 30-43.

Ministry of Health Spain (2020a), Situación de Covid-19 en España, available at: https://cnecovid.isciii. es/covid19/\#ccaa (accessed 31 May 2021).

Ministry of Health Spain (2020b), Actualización no 218. Enfermedad por el coronavirus (COVID-19). 30.09.2020, available at: https:/www.mscbs.gob.es/profesionales/saludPublica/ccayes/ alertasActual/nCov/documentos/Actualizacion_218_COVID-19.pdf (accessed 31 May 2021). 
BFJ 123,13

Nielsen (2020), Recalibrated Consumption Dynamics in a COVID-19 Altered World, available at: https:// www.nielsen.com/us/en/insights/article/2020/recalibrated-consumption-dynamics-in-a-covid-19altered-world/ (accessed 14 December 2020).

Organisation for Economic Co-operation and Development (OECD) (2020), The Territorial Impact of COVID-19: Managing The Crisis Across Levels of Government, available at: http:/www.oecd. org/coronavirus/policy-responses/the-territorial-impact-of-covid-19-managing-the-crisis-acrosslevels-of-government-d3e314e1/ (accessed 28 February 2021).

Padel, S. and Foster, C. (2005), "Explore the gap between attitudes and behavior. Understanding why consumers buy or do not buy organic food", British Food Journal, Vol. 107 No. 8, pp. 606-625.

Patel, J.D., Rivedi, R.H. and Yagnik, A. (2020), "Self-identity and internal environmental locus of control: comparing their influences on green purchase intentions in high-context versus lowcontext cultures”, Journal of Retailing and Consumer Services, Vol. 53, doi: 10.1016/j.jretconser. 2019.102003.

Rahimah, A., Khalil, S., Cheng, J.M.-S., Tran, M.D. and Panwar, V. (2018), "Understanding green purchase behavior through death anxiety and individual social responsibility: mastery as a moderator", Journal of Consumer Behaviour, Vol. 17 No. 5, pp. 477-490.

Rahmani, D., Kallas, Z. and Gil, J.M. (2020), Impacte de la COVID19 en la compra $i$ el consum d'aliments, available at: https://www.upc.edu/ca/sala-de-premsa/pdfs/presentacio-estudiimpacte-covid-19-consum-alimentari.pdf/view (accessed 31 May 2021).

Rana, J. and Paul, J. (2017), "Consumer behavior and purchase intention for organic food: a review and research agenda”, Journal of Retailing and Consumer Services, Vol. 38, pp. 157-165.

Reich, B.J., Beck, J.T. and Price, J. (2018), "Food as ideology: measurement and validation of locavorism", International Journal of Consumer Research, Vol. 45 No. 4, pp. 849-868.

Rodríguez-Pérez, C., Molina-Montes, E., Verardo, V., Artacho, R., García-Villanova, B., GuerraHernández, E.J. and Ruíz-López, M.D. (2020), "Changes in dietary behaviours during the COVID19 outbreak confinement in the Spanish COVIDiet study", Nutrients, Vol. 12 No. 6, pp. 17-30.

Sarstedt, M., Hair, J.F., Cheah, J.H., Becker, J.M. and Ringle, C.M. (2019), "How to specify, estimate, and validate higher-order constructs in PLS-SEM", Australasian Marketing Journal, Vol. 27 No. 3, pp. 197-211.

Scharber, H. and Dances, A. (2016), "Do locavores have a dilemma? Economic discourse and the local food critique", Agriculture and Human Values, Vol. 33 No. 1, pp. 121-133.

Schmitt, E., Galli, F., Menozzi, D., Maye, D., Touzard, J.M., Marescotti, A., Six, J. and Brunori, G. (2017), "Comparing the sustainability of local and global food products in Europe", Journal of Cleaner Production, Vol. 165, pp. 346-359.

Sheth, J. (2020), "Impact of Covid-19 on consumer behavior: will the old habits return or die?", Journal of Business Research, Vol. 117, pp. 280-283.

Shmueli, G., Sarstedt, M., Hair, J.F., Cheah, J.-H., Ting, H., Vaithilingam, S. and Ringle, C.M. (2019), "Predictive model assessment in PLS-SEM: guidelines for using PLSpredict", European Journal of Marketing, Vol. 53 No. 11, pp. 2322-2234.

Singh, A. and Verma, P. (2017), "Factors influencing Indian consumers' actual buying behavior towards organic food products", Journal of Cleaner Production, Vol. 167, pp. 473-487.

Spielmann, N. and Bernelin, M. (2015), "Locavores: where you buy defines who you are”, International Journal of Retail and Distribution Management, Vol. 43 No. 7, pp. 617-633.

Statista (2021), "Volumen de negocio del comercio electrónico en los hipermercados, supermercados y tiendas de alimentación dentro de España del primer trimestre de 2014 al segundo trimestre de 2020", available at: https:/es.statista.com/estadisticas/718236/supermercados-y-tiendas-dealimentacion-facturacion-interna-en-ecommerce-espana (accessed 31 May 2021).

Sun, Y., Liu, D., Chen, S., Wu, X., Shen, X.-L. and Zhang, X. (2017), “Understanding users' switching behavior of mobile instant messaging applications: an empirical study from the perspective of push-pull-mooring framework", Computers in Human Behavior, Vol. 75, pp. 727-738. 
Tomic, M., Matulic, D. and Jelic, M. (2015), "What determines fresh fish consumption in Croatia?", Appetite, Vol. 106, pp. 13-22.

Trivedi, R.H., Patel, J.D. and Savalia, J.R. (2015), "Pro-environmental behaviour, locus of control and willingness to pay for environmental friendly products", Marketing Intelligence and Planning, Vol. 33 No. 1, pp. 67-89.

Vabø, M. and Hansen, H. (2016), "Purchase intentions for domestic food: a moderated TPBexplanation”, British Food Journal, Vol. 118 No. 10, pp. 2372-2387.

Wu, H.-C. and Cheng, C.-C. (2016), "Synthesizing the effects of green experiential quality, green equity, green image and green experiential satisfaction on green switching intention", International Journal of Contemporary Hospitality Management, Vol. 28 No. 9, pp. 2080-2107.

Wu, H.-C., Wei, C.-F., Tseng, L.-Y. and Cheng, C.-C. (2018), "What drives green brand switching behavior?”, Marketing Intelligence and Planning, Vol. 36 No. 6, pp. 694-708.

Xie, X., Huang, L., Li, J. and Zhu, H. (2020), "Generational differences in perceptions of food health/risk and attitudes toward organic food and game meat: the case of the COVID-19 crisis in China", International Journal of Environmental Research and Public Health, Vol. 17 No. 9. doi: 10.3390/ ijerph17093148.

Xin, L. and Seo, S. (2020), "The role of consumer ethnocentrism, country image, and subjective knowledge in predicting intention to purchase imported functional foods", British Food Journal, Vol. 122 No. 2, pp. 448-464.

Yildirim, M. and Güler, A. (2020), "Factor analysis of the COVID-19 perceived risk scale: a preliminary study”, Death Studies. doi: 10.1080/07481187.2020.1784311.

Zhang, T., Grunert, K.G. and Zhou, Y. (2020), "A values-beliefs-attitude model of local food consumption: an empirical study in China and Denmark", Food, Quality and Preference, Vol. 83, doi: 10.1016/j.foodqual.2020.103916.

\section{Further reading}

Pearson, D., Henryks, J., Trott, A., Jones, P., Parker, G., Dumaresq, D. and Dyball, R. (2011), "Local food: understanding consumer motivations in innovative retail formats", British Food Journal, Vol. 113 No. 7, pp. 886-899.

Schuitema, G. and de Groot, J.I.M. (2015), "Green consumerism: the influence of product attributes and values on purchasing intentions", Journal of Consumer Behaviour, Vol. 14 No. 1, pp. 57-69.

Perceived risk of COVID-19 on consumers 
BFJ

123,13

\section{Appendix}

\begin{tabular}{llll}
\hline Variable & Dimensions & Items & Source \\
\hline COVID-19 & Cognitive (COG) & Perceived likelihood of acquiring & $\begin{array}{l}\text { Yildirim and Güler } \\
\text { perceived risk }\end{array}$ \\
COVID-19
\end{tabular}

(CPRS)

Perceived likelihood of acquiring

COVID-19 compared to other persons

Perceived likelihood of other diseases

(e.g. diabetes/asthma)

Perceived likelihood of dying from

COVID-19

Emotional (EMO) Worry about oneself contracting

COVID-19

Worry about a family member

contracting COVID-19

Worry about COVID-19 occurring in the region

Worry about COVID-19 emerging as a health issue

Locavorism Lionization (LIO)

Locally produced foods just taste better

(LOCAV)

All else being equal, there is no difference in taste between a locally produced food and one that was shipped from

somewhere else

Locally produced foods are more

nutritious than foods that have been

shipped from somewhere else

Opposition (OPP) I do not trust foods that have been produced by large multinational corporations

Large global food systems are destined to fail

I would go out of my way to avoid buying

food from a large retail grocery chain

I feel uneasy eating something unless

I know exactly where it was produced

Communalization

Buying locally produced foods supports

(COM)

Internal locus of

control (INLOC)

Table A1.

Measurement

sustainable farming practices

Buying local foods helps build a more

prosperous community

I like to support local farmers whenever possible

Supporting the local food economy is important to me

It is acceptable to pay more for groceries that are produced, processed and

packaged by local producers

I would accept paying more taxes for a governmental program to protect locally produced food companies

I would be willing to spend an extra per week in order to buy food that is less processed and to buy food that is produced and packaged zero miles away

Adapted from Cleveland et al. (2005) 


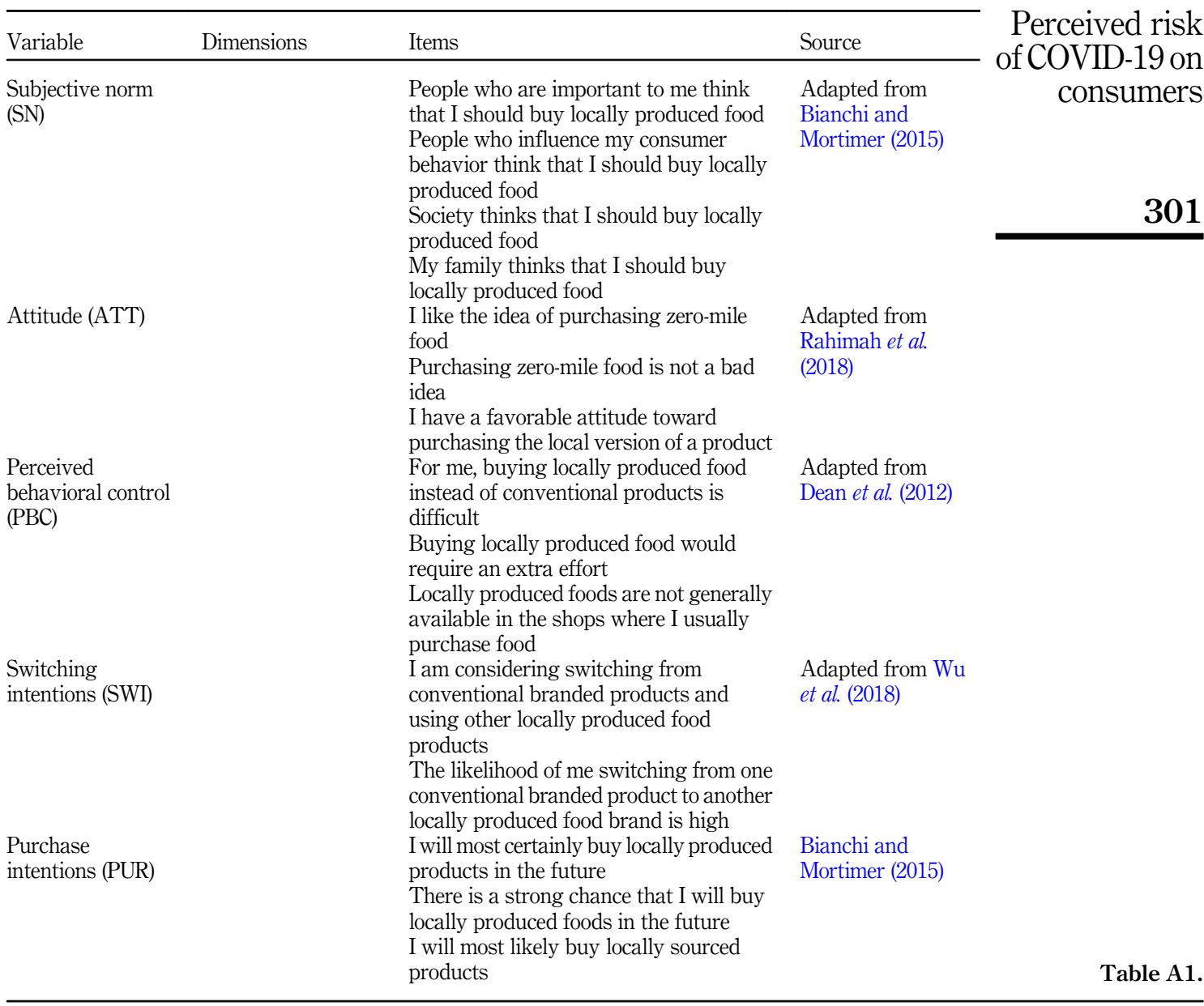

\section{Corresponding author}

Ramon Palau-Saumell can be contacted at: ramon.palau@iqs.url.edu

For instructions on how to order reprints of this article, please visit our website:

www.emeraldgrouppublishing.com/licensing/reprints.htm

Or contact us for further details: permissions@emeraldinsight.com 